\title{
Bringing the Museum into the Classroom, and the Class into the Museum: An Approach for Content-Based Instruction
}

\author{
Kathryn Sederberg \\ University of Michigan
}

\begin{abstract}
Through the example of a fourth-semester course on modern German history, this article explores the application of interactive and experiential learning models inspired by museum pedagogy. In response to the ACTFL Standards and the 2007 MLA report, the teaching of culture has become a priority and educators continue to seek innovative ways to teach culture and to attain the goals of "comparisons" and "connections," as well as translingual and transcultural competence. This article demonstrates that museum strategies can be productively transferred to content-based foreign language instruction to provide learning experiences in which students interact critically with the objects of cultural archives. Both actual and virtual museum visits, as well as the integration of primary materials in the classroom, can further students' transcultural competence and critical thinking about the interrelations of culture and language, as well as provide intellectually and aesthetically engaging learning experiences.
\end{abstract}

In a discussion of her book The Multilingual Subject, Claire Kramsch emphasizes that more attention should be paid to the "aesthetic dimension of learning," and to the fact that learners acquire language "with all their senses" (2012, p. 76). This has long been recognized in the field of museum pedagogy, which emphasizes the experiential and multi-dimensional nature of learning, engaging the senses and intellect in study of the museum's objects. Museum educators often cite John Dewey's Art as Experience as foundational for theorizing the affective component of learning and the kind of experience the museum can facilitate. In this article, I show how aspects of museum teaching can be productively applied to content-based foreign language (FL) instruction. Through the example of a fourth-semester course on modern German history, taught in German, and including museum visits, this article provides concrete examples of how interactive and experiential learning models can help instructors design, teach, and assess content-based courses. This approach can help instructors incorporate museums into their courses, as well as interdisciplinary work with primary sources and a focus on the affective dimension of learning.

In what follows, I first briefly summarize the literature on content-based instruction (CBI) and situate it within the context of the ongoing discussion of the 2007 MLA report on "New Structures for a Changed World," and also within the context of the ACTFL Standards " 5 Cs" (National Standards, 2006). I go on to highlight key aspects of museum pedagogy and show how strategies inspired by the museum can be productively integrated into content-based language courses, and how doing so can help us work towards the MLA and ACTFL goals. I not only suggest ways of bringing the class into the museum, literally or virtually, but also ways of bringing the museum into the classroom, engaging students with a range of different sources 
and cultural objects. This approach furthers language-learning goals and focuses on the learners' subjective experience, as well as critical thinking skills, and can help them make connections and comparisons with other cultural and disciplinary contexts. I conclude with a presentation of some ways in which the ideas discussed in this article could be applied in a range of courses.

\section{Context: Teaching Language and Culture in a "Changed World"}

The 2007 MLA report on "New Structures for a Changed World" has of course been widely discussed in the past few years, yet the ambitious goals presented in that document remain a challenge for many foreign language educators. The report identifies the integration of language and content instruction in the curriculum as an unfinished project, and calls for further contextualization of language instruction within "cultural, historical, geographic, and cross-cultural frames" (MLA, 2007, p. 4). In addition to language proficiency, students should gain the ability to "reflect on the world and themselves" and "consider alternative ways of seeing, feeling, and understanding things" (p. 4). Ultimately, language departments should produce students with "deep translingual and transcultural competence"(p. 3).

These goals share notable affinities with the five goal areas presented in the ACTFL Standards for Foreign Language Learning: Communication, Cultures, Connections, Comparisons, and Communities (2006). Of these 5 Cs, a 2011 follow-up study shows that although instructors feel comfortable teaching Cultures and Communication, there remains some confusion regarding how to teach the other goals, especially Communities ("the vision of language as having a real world communicative use") and Connections (Abbott \& Phillips, pp. 6, 26). The study found that although the Connections standard could be used to promote interdisciplinary work, this is rarely done. Instructors complained that they found it "difficult to connect to other disciplines/departments," and that they had a "lack of resources" and "lack of knowledge of how to address this goal area" (p. 29). What is at stake here is thus not only the integration of language and cultural content, but also how to address the extra-linguistic goals of language instruction, and how to create meaningful contexts for language learning that cross disciplinary boundaries. Instructors also need more strategies for implementing and assessing these goal areas.

Content-based instruction $(\mathrm{CBI})$ has become widely recognized as an approach that is ideally suited to integrating the teaching of language and culture, and to making interdisciplinary teaching possible (for an overview, see Dueñas, 2004). By engaging students in subject matter they find interesting, and by using authentic target language materials, CBI aims to make students' language output more natural, and to help students make new connections among language, culture, and society. Successful content-based courses therefore make classroom communication more meaningful and often integrate "learner-centered as well as inquirybased pedagogies that engage students more fully" (Lyster \& Ballinger, 2011, p. 286).

Teaching content-based courses can involve a difficult balance between linguistic and other goals. Met (1998, p. 43) places content-based courses on a continuum, between "languagedriven programs" (in which content goals are subsidiary to language goals, and students are not held accountable for achieving the content goals), and "content-driven programs" (in which this hierarchy is reversed). In order to work towards the goals set out by the MLA report and by the ACTFL Standards, content-based FL courses need to balance both ends of this continuum, that is, the language and content goals of the course. This poses a consistent challenge for course design and assessment, and for integration into larger curricular goals (Stoller, 2004).

Despite the challenges of teaching content with language, studies of CBI are overwhelmingly positive in their evaluation of the approach and its results. Studies have shown that CBI not only furthers linguistic abilities, but also content knowledge (Rodgers, 2006). Dupuy 
suggests that $\mathrm{CBI}$ may not only help students transition from beginning to advanced language courses, but that it also motivates many to continue language study (2000). Recent publications in Die Unterrichtspraxis/Teaching German speak to the wide range of creative possibilities for designing language courses organized through a cultural theme: cabaret (Bell), opera (Heinz), engineering (Rarick), the Wende (Streitwieser \& Lys), young adult literature and the Holocaust (Schulz), among others. These instructors show how CBI not only targets language skills, but also motivates students to learn and better understand German culture. CBI, therefore, not only brings together language and content teaching, but also works towards the goals of Communities and Connections.

\section{A Museum-Based Approach: Foreign Language Learning as Experience}

In this section, I highlight characteristics of a museum-based approach that can be applied in content-based courses, and I show how this will further the more elusive goals of Connections, Communities, and Comparisons, in addition to Communication and Culture goals. Like CBI itself, this approach is not a fixed method but rather a framework for language teaching, applicable to many different contexts and courses within the larger $\mathrm{CBI}$ framework. As stated in the introduction, a museum-based approach integrates aesthetic and intellectual goals, learnercentered teaching models, and interactive and experiential learning. Below, I outline three benefits of museum learning in the FL context: First, because of the emphasis on interactive engagement, this approach furthers the affective and aesthetic experience of the student. Second, in a very material sense, learning in and with museums offers access to cultural archives of the target culture, requiring and honing critical skills for reading and interpreting these objects. Third, museum-based learning promotes connections across contexts and disciplines; it is by nature contextual, combining personal, socio-cultural and physical spheres.

First, let us consider the aesthetic dimension of learning and its relation to student engagement. The subjective experience of the learner has often been overlooked in language learning methodologies, as Kramsch argues: "Pleasure has not entered the vocabulary of Second Language Acquisition. It is not generally a word you use because most SLA research has not taken into account the sensuous material aspect of language learning" (2012, p. 78). She points out the physical pleasure non-native speakers may experience with language, becoming aware of and experiencing the sound and feel of words and phrases.

Museum pedagogy has always emphasized the subjective dimension of learning, and that instructors should provide a learning experience, facilitating interactions that produce "transforming insights" (Carr, 2001, p. 8). In fact, museum educators often have goals that are not easily quantifiable: in particular, to promote interest and curiosity, so students will want to continue learning and return to the museum (Tran, 2007, p. 294). The goal of the museum is not so much to provide answers, or "mere knowledge," but rather to facilitate "the processes of inquiring, consulting, assembling, evaluating, constructing" (Carr, p. 10; 14).

These goals are not unlike our own in German language teaching, as we move to integrate subject-centered interactive processes with outcome goals based on the Standards. In an essay on "what people learn in the art museum," Danielle Rice writes that there is a prevailing sense of a dichotomy between cognition versus sensation: for example, learning about art (the "library" model), or enjoying art (the "temple" model) (2001, p. 43). As educators we need to bridge this false divide by harnessing the aesthetic experience to engage students to make meaningful connections to the objects in our classroom "archive."

Student engagement, conceived as a "multidimensional construct" including behavioral and subjective components, has been found to positively affect learning outcomes (Handels- 
man et al. 2005, p. 190). By recognizing the affective and multi-sensory experience of the language learner, instructors can help foster not only classroom learning, but also long-term intellectual curiosity in students (Kramsch, 2009, pp. 202-211). In discussion of student engagement in museum learning, Carr offers the transformative concept of "mindfulness": "the generative ability to pay attention, encourage reflection, and to think flexibly of contexts and ideas. This is the quality - cognitive activity — that allows us to become different people than the ones we were this morning. Mindful use of a museum or a library transforms us" (2001, p. 15).

This transformative ability to reflect, "think flexibly" and make connections across disciplinary contexts brings us to the second aspect of museum learning which should be considered: the relationships among object, language, and learner, and the skills needed to "read" these objects. This approach helps us recognize the importance of materiality (an original vs. a digital reproduction) and place (the museum vs. the classroom), and how this may affect learning. Hooper-Greenhill, in Museums and the Shaping of Knowledge, writes of the "radical potential of material culture, of concrete objects, of real things, of primary sources" (1992, p. 215). Her claim is that these objects are powerful because of their ability to be "reread": "As long as museums and galleries remain the repositories of artefacts and specimens, new relationships can always be built, new meanings can always be discovered, new interpretations with new relevances can be found, new codes and new rules can be written" (p. 215).

As FL instructors, we consistently introduce our students to such primary sources and cultural "objects" in the classroom, for example: visual art (Barnes-Karol \& Broner, 2010; Knapp, 2012; Scanlan, 1997), physical objects (Shuh, 1999), and texts (García, 1991). Although we use such objects, we perhaps do not always consider the material dimension, or their framing as objects of a cultural archive. Our task is to provide students with the conceptual and linguistic tools required to access these "historical, geographical, cultural, and literary archives" of the target culture, as part of the goal of transcultural education (Pratt et al., 2008, p. 290). We also need to guide students in reading and interpreting these objects-whether they be historical sites, maps, literary works, photographs, film, or other realia to be used as such "primary sources." To do this, we need to practice the skills of close reading and interpretation, and to teach students how to historicize and frame objects. Multiple studies have shown the benefits of integrating critical thinking goals with language learning goals in such a way (Benesch, 1999; Pally, 2001; Stroupe, 2006).

The third way a museum approach can help FLeducators is through the necessarily interdisciplinary setting. Bringing language classes to museums-whether art museums, library special collections, archives, or history museums - places them in new contexts for using their language skills. In Learning from Museums, Falk and Dierking offer a "Contextual Model of Learning" involving "three overlapping contexts: the personal, the sociocultural, and the physical" (2000, p. 10). They also stress the temporal delay in contextual learning, a "never-ending integration and interaction of these three contexts over time in order to make meaning" (p. 11). The long-term, processual nature of such learning, however, presents challenges for measuring outcomes. In a fascinating study of visitor response, Falk and Dierking show that museum learning is often delayed. They discovered that although most visitors made only brief comments related to exhibit content immediately after their visit, when interviewed months later, visitors had "new insights, a number of new ideas, and an overall renewed excitement and interest in [the subject]" (p. 7).

This study has several implications for FL teaching, and specifically for content-based courses. Although certain FL competencies may be measured by tests, essays, and oral exams, it is difficult to measure the goals of transcultural competence, "connections," "comparisons," or the kind of interdisciplinary critical thinking promoted by CBI. The "Contextual Model" conceptualizes learning as a trajectory, unique to each student, ending long after they leave our classrooms. Following Falk and Dierking, one possibility for assessing this kind of long-term 
learning process might be to follow-up with students months after the course, and conduct surveys about whether they later made new observations or connections related to course material. Another possibility might be to have intermediate and upper-level students reflect upon the "culture" aspects of their previous FL courses, and to reflect on connections they have made between these and courses in other fields.

Alternately, Short suggests a more "holistic" assessment matrix for CBI to test language and content goals, including categories such as problem solving, concept comprehension, and group behavior (1993). This list of skills may be assessed through means such as portfolios, essay writing, or student self-evaluations, for which Short lists advantages and disadvantages. Such surveys, interviews, and self-reflections may also foster the kind of comparisons and connections we are hoping to generate as an outcome of CBI.

\section{Teaching with and in Museums: German History for Learners of German}

In the remainder of the article I provide the example of a fourth-semester, content-based course on modern German history that was designed to incorporate the kind of experiential, interactive, and interdisciplinary learning that happens in museums. The goals of the course were to introduce students to some of the major events and themes from German history, and to foster the development of their language skills by actively engaging them with this topic in German. Students were tested on the content, and the content served as a context for improving their communicative competence in the language. In the course of the semester, we also practiced transferable skills in interpretation and critical analysis. Grades for homework, participation, and essays, as well as the writing sections of tests, were based equally on content and language. Tests also included sections that explicitly targeted vocabulary and grammar.

\section{Course Design}

Because this course was intended to introduce intermediate language students to modern German history, and demanded no previous knowledge, we worked within the broad timeline 1871-1989. This complemented our department's third-semester course which has units on the Wende and contemporary issues in German society. Only one of the 25 students was a history major, and only two had previously taken a course on German history. When asked why they took this course, many students mentioned an interest in WWII, and most were unfamiliar with German history before this period. Some students chose the section because of scheduling and not because of the topic. Because we could not cover the chosen period exhaustively, I focused on major turning points, persons, and events in German history that were relevant and potentially interesting to students.

In order to introduce Germany's historical and cultural archives in ways that would engage students, I strove to add variety to our classroom routine and to introduce them to many different kinds of primary sources, including textual, visual, and filmic media. This not only made the class interesting, but also more interdisciplinary, exposing students to the many subfields related to German Studies (architecture, art, music, literature, etc.). The course included two museum field trips (during class time), four guest speakers, and six sessions in the Language Resource Center's computer lab. In their final evaluations, 8 of the 21 respondents specifically mentioned the variety of activities as a positive aspect of the course.

In accordance with limitations of time and of students' language proficiency, much of the historical material was treated in a less detailed manner than it would be in a course in the 
history department. These are necessary results of adapting the material to the level of language learners, and should not be surprising. To compensate for these compromises in balancing language and content, I emphasized the development of students' critical thinking skills - a goal that can be applied at all language levels (see Mihaly, 2006, on the "stealth approach to critical thinking"). It is in this context that museum-based learning was especially useful. By interacting with historical sources as objects of Germany's archives, we practiced close reading and interpretation skills transferable to other disciplines and a wide variety of media. While students could not master the language of art-historical discourse, for example, they were still able to describe and interpret Expressionist drawings in creative, personal, and meaningful ways. See Appendix A for examples of essay prompts that require personal reflection on the material.

\section{Materials}

Course materials were compiled from the web (see Appendix B for an extensive list of history-related resources) and from published textbooks, including Andreas Lixl-Purcell's (1991) Stimmen eines Jahrhunderts, with excellent and well-glossed primary sources, and Wolf Köpke's (1999) Die Deutschen, providing secondary summaries of historic periods. The assigned readings included literary texts such as Brecht's poetry, a letter from Sophie Scholl to her fiancé, and diary excerpts from Käthe Kollwitz. I selected authentic materials according to the criteria suggested by Brinton, Snow, and Wesche (2003, p. 90): content authenticity, difficulty level, textual aids, and source.

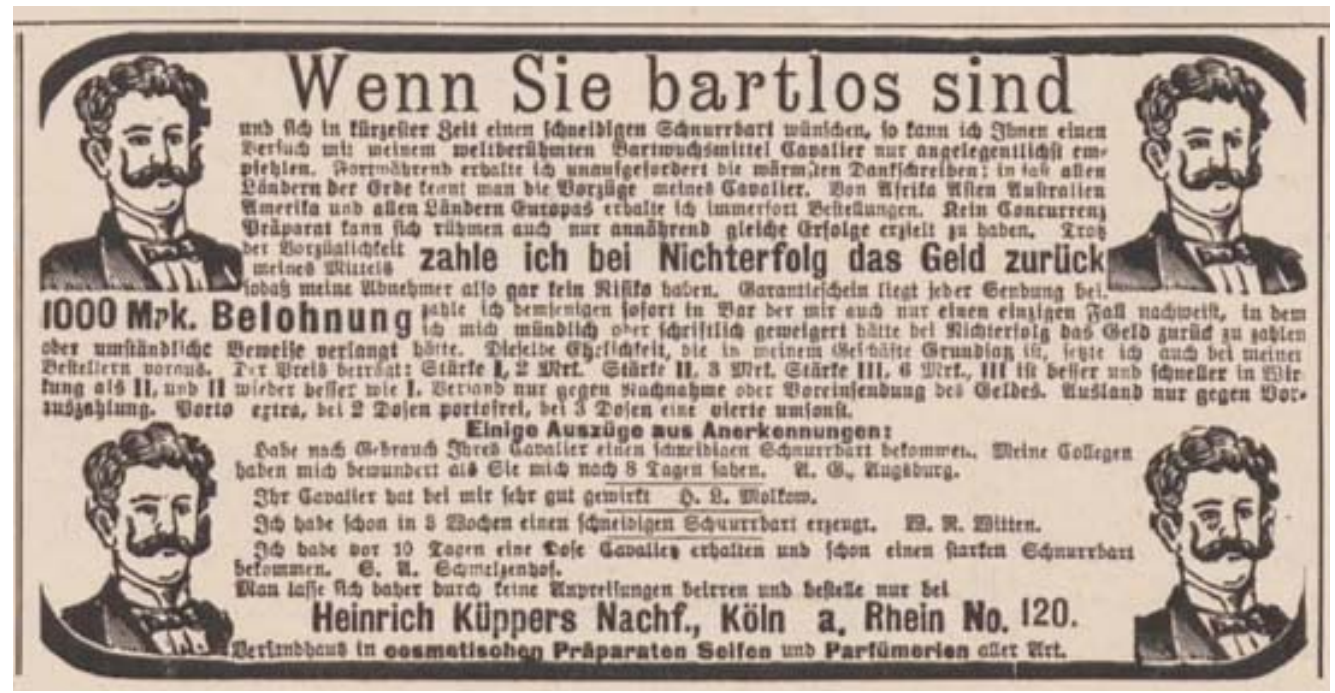

Figure 1. Kaiserreich-Era Advertisement (Heinrich Küppers Nachf., 1906)

\section{Group Activities: Interactive Work with Primary Sources}

Materials for content-based courses will typically include challenging, and often unglossed, authentic sources. In order to work with these materials at the students' proficiency level, I followed the principle of adapting the task, not the text (Rutherford, 1987). In this way, even dif- 
ficult texts can be used in productive ways by asking students to read for specific items, a "linguistically simple but cognitively challenging task" (Stryker \& Leaver, 1997, p. 297). These tasks are made more interactive and engaging in group activities.

For example, for an in-class group activity, students read advertisements from the early 1900s by skimming the headlines and slogans, using visual organizers to facilitate comprehension (see Figure 1). In class, we began with a pre-reading activity in which we discussed advertising in general, its goals, and relations between text and image. Students then "read" through the Kaiserreich-period ads in small groups, making lists of products that were being sold/advertised, and slogans that they understood. Among ads for typewriters, shoes, revolvers, and cigarettes, there were also the recognizable brands BMW and FIAT with images. In the follow-up, we discussed what we can learn from the products about leisure activities and "modern" technology of the time, how these ads are gendered, and we made comparisons with advertising today. See Appendix $C$ for another example of an interactive group activity with primary sources.

Throughout the semester we practiced a critical approach to reading primary and secondary sources from Germany's cultural archives. Students learned to practice close analysis: identifying the medium and intended audience and considering the social, cultural, and political context. These are skills applicable to multiple disciplines and relevant in everyday life in the encounter with textual or visual media. Such activities also advance the desired competencies listed in the MLA report: "critical language awareness, interpretation and translation, historical and political consciousness, social sensibility, and aesthetic perception" (p. 4).

\section{Museum Visits: Physical and Virtual}

Our first museum experience was a visit to the Map Library on campus. I worked with a librarian to select maps relevant to German history. The maps included: medieval papyri in which one can make out major rivers of present-day Germany; US military intelligence maps of interwar Germany; maps of the Berlin Wall; a red Baedeker guide from the late 1880s; Nazi maps promoting Autobahn tourism and the 1936 Olympics; and 19th-century maps of the expanding railway system. The main goal of the session was to introduce students to an archive and to primary sources, and to provide them with objects from widely different contexts. By comparing maps from such different historical periods, students saw the dramatic changes in Germany's borders, and the many different purposes for mapping this region. We discussed the maps' authors and possible intended audiences, the goals of the publication, and the size and material of specific maps.

During the first part of the hour, the librarian introduced the collection and the resources of the library in general. For most students, this field trip was their first exposure to archival sources and to a research librarian. The students then had time to move freely and explore the maps that looked interesting to them. They walked around and examined the materials, and I circulated and provided background information and language support in German. One student, looking at a map showing the Berlin Wall, saw the checkpoint "Sonnenallee," and started showing his classmates. He recognized the name from a book they had read in a previous German class (Thomas Brussig's Am kürzeren Ende der Sonnenallee). I could see his excitement in making this connection: linking a piece of literature to a map of Berlin. In his homework, he wrote, "Ich habe die Straße (Sonnenallee) auf der Karte gesehen. Ich habe gedacht, dass das wirklich cool war." Another student mentioned the same connection in her response.

In a follow-up writing assignment, students made observations about their favorite maps, which made for more focused, specific responses, and personal connections. They noticed details such as borders and illustrations, hypothesized about intended audiences, and made 
insightful connections between the maps and historical events or periods. The students' evaluations of the visit were very positive, and I would highly recommend maps as a basis for content-based lessons. Many campus libraries have maps or map guidebooks in their collection, and even contemporary maps, photocopies, or digital maps could generate fascinating class sessions.

Asking creative questions about any such primary sources can provide for a productive transcultural analysis. For example, I asked students about the "Ring" and where cities used to have a city wall; where the Bahnhof is usually located, and how the street names compare to those in the US. Another application of map sources for beginning levels could be to use Google Maps to look up an address in a German town as well as the students' home addresses, and compare what they find in a 2-kilometer radius. Such tasks work towards the Cultures, Connections, and Comparisons goals, by requiring reflection on cultural differences and similarities.

The second museum visit was to the campus art museum, where fifteen original drawings were brought out of storage for our use, and a docent was present for questions. Students studied original works by Otto Dix, Käthe Kollwitz, George Grosz, and Ernst Ludwig Kirchner, moving from piece to piece, speaking German, making notes and discussing their interpretations. While in the museum, students were asked to first describe what they saw, paying attention to adjective endings; and second, to interpret what they saw. In doing so, they practiced the language required for visual descriptions and for first-person interpretation and value statements.

Their homework, a written repetition of this same task, produced impressive results (spelling/grammar unaltered):

\footnotetext{
"Der Kriegsheld fühlte wahrscheinlich nicht wie einen Held."

"Mit Hilfe dieses Bildes zeigt der Autor den Unterschied der Klassen in den 1920er Jahren."

"Das Baby symbolisiert Hoffnung und ein neue Leben nach dem Krieg"

"Da ist ein interessanter Kontrast zwischen den Krieg und Religion."

"Ich glaube, dass [das Licht] symbolisiert, wenn Mann keine Hoffnung vom dem Äußere bekommt, muss er innerhalb suchen. Dieses Bild war sehr stark für mich."
}

As seen in these examples, students not only made astute observations and interpretations, but offered subjective comments on the feelings of the painting, and their favorites. Such remarks demonstrate an interaction that was personal and required not only critical analysis, but mindful thinking and aesthetic engagement.

Making the most of these museum visits requires advance organizers and pre-reading activities to help students activate the vocabulary and grammar they will need. These can be structured to give students more control over their learning, resulting in increased enthusiasm and curiosity (on free-choice learning, see Falk \& Dierking, 2002). For example, in preparation for the art museum we reviewed adjective endings, and learned vocabulary to describe visual art. In class, I introduced interwar Expressionism, and students practiced describing a few paintings in groups. For homework, they chose one or two artists from a list of the artists they would encounter in the museum the next day. They looked up examples of their work online and wrote descriptive paragraphs (with specific attention to adjective endings). During the visit, I noticed that they were drawn to works by "their" artist, which suggests that those activities provided a more meaningful starting point.

In addition to these two museum visits, the course also included two "virtual visits" to German museums: the Deutsches Historisches Museum (DHM) and the Berliner Synagoge. These were chosen because of exhibits that fit well with course material, and the resources avail- 
able on the museum websites. The first assignment was designed around the controversial DHM exhibit "Hitler und die Deutschen," with a website including a map of the exhibition, as well as photographs of its objects. The second virtual visit was the exhibition "Reichspogromnacht" at the Berliner Synagoge. Students watched a short video about the exhibit (on the museum website), and answered open-ended questions. Because the language of the video was too difficult for students (no subtitles), I adapted the task so that we could still use the materials. Providing a short summary of the contents, I asked more global questions, mostly related to the visual content: Schreiben Sie über die Bilder, die Sie sehen. Würden Sie diese Ausstellung besuchen wollen? Welche Fragen haben Sie?

These "digital" visits were much more challenging for students. As quoted above, part of the appeal of the museum is the access to "concrete objects" and "real things." The Internet allows instructors to provide authentic input and a variety of media, but it lacks the affective engagement of an actual museum visit, or the tangible interaction with objects in the classroom. To meet this challenge, instructors should link the virtual visits to classroom discussions, homework and/or projects that make the material more approachable. Giving students more choice in choosing a German museum to "explore" online may also increase interest. Actual visits to sites on campus or nearby remain the more ideal setting for learning.

\section{Conclusion}

The overwhelmingly positive student evaluations at the end of the course demonstrate engagement with, and appreciation for, the course content, variety of materials, and activities. One student wrote at the end of the semester,

\footnotetext{
Your course has been my favorite that I have taken so far at the university. I really appreciated that you were able to convey the information to us through a diverse array of mediums. I had abandoned all hope years ago of ever taking a field trip again, but you really came through for me on that one.
}

Students recognized that they had been "surveying German history through interesting lenses," and "interact[ing] with each other while engaging in the language" during group activities. Many also mentioned an appreciation for the films, essays, presentations, and computer resources for building their language proficiency. In addition to this anecdotal evidence, I could observe students' application of new vocabulary and concepts in homework, essays, and tests, and their increased ability to interpret both visual and textual sources.

This article has described and offered some suggestions for the application of museumbased interactive and experiential learning models in content-based language classes. This approach can be applied at the level of the lesson or unit (ranging from a day or weeks), or in designing an entire course (perhaps even about museums and their objects). First, incorporating physical museum visits provides an ideal interdisciplinary context for learning. Instructors should prepare students for these visits, and take care to balance aesthetic and intellectual goals: students should make personal connections with the objects of the museum and should also be asked to reflect critically on material, historical, and cultural aspects of sources.

Second, this article suggests ways to help students access the historical and cultural archives of German Studies, including as its "objects" literature, maps, advertisements, and works of art. This will help us work towards the interdisciplinary goals of Connections and Comparisons, if we can help our students practice critical reading skills transferable from their FL classroom into other disciplinary and real-world contexts. And third, a museum approach reminds us to consider the subjective dimension in learning a foreign language. To make learning more meaningful, our classroom and homework tasks should involve personal reflection, invite 
comparison and contrast between cultures, and should also consider that learning is a contextual process unique to each student. In doing so, we will work toward the goals of the Standards and the MLA report-especially the goals of transdisciplinary connections while teaching culture and language. Going outside the classroom and using physical objects in the classroom also promotes the "pleasure" involved in learning, and it engages students' multiple senses in the learning process. As Burnham and Kai-Kee (2005, p. 75) write,

\footnotetext{
Museums are places of possibility. But possibilities are only made real when educators skillfully use the broad knowledge and understanding they have of objects throughout their museums to inspire and encourage people to dream a little with them, and to make them their own.
}

Likewise, the classroom is a place of possibility, a mere setting for the objects, texts, and images we bring into it and with which we incite the curiosity and desire for knowledge of our students. Thinking about incorporating strategies from museum learning into our teaching is one way to place culture at the core of language instruction, and to provide learning experiences for our students that will stay with them after the semester is over, helping them think more critically and mindfully about the connections between language and culture, and gain skills to read the objects of cultural archives.

\section{Acknowledgments}

I would like to thank the editors of Unterrichtspraxis, as well as the anonymous reviewers for their feedback. Many thanks are also due to Hartmut Rastalsky for his support and mentorship, to Map Librarian Tim Utter for introducing my students to the Map Library and its resources, and to the University of Michigan Museum of Art for welcoming students to use its collections.

\section{Works Cited}

Abbott, M. G., \& Phillips, J. K. (2011). A decade of foreign language standards: Influence, impact, and future directions: Survey results. US Department of Education. Title VI: International Research and Studies Program. http://www.actfl.org/ sites/default/files/pdfs/public/national-standards2011.pdf.

Barnes-Karol, G., \& Broner, M. A. (2010). Using images as springboards to teach cultural perspectives in light of the ideals of the MLA Report. Foreign Language Annals, 43 (3), 422-445.

Bell, M. R. (2010). Making connections to energize students: Exploring the language-culture nexus through German Kabarett. Die Unterrichtspraxis/Teaching German, 43 (2), 111-122.

Benesch, S. (1999). Thinking critically, thinking dialogically. TESOL Quarterly, 33 (3), 573-580.

Brinton, D. M., Snow, M. A., \& Wesche, M. (2003). Content-based second language instruction. Ann Arbor, MI: The University of Michigan Press.

Burnham, R., \& Kai-Kee, E. (2005). The art of teaching in the museum. The Journal of Aesthetic Education, 39 (1), 65-76.

Carr, D. (2001). The need for the museum. In D. Carr, R. Eskridge, H. Jensen Leichter, D. Rice \& A. V. F. Storr (Eds.), The museum as a place for learning (pp. 7-15). Ithaca, NY: Cornell University Press.

Dueñas, M. (2004). The whats, whys, hows and whos of content-based instruction in second/foreign language education. International Journal of English Studies, 4 (1), 73-96.

Dupuy, B. C. (2000). Content-based instruction: Can it help ease the transition from beginning to advanced foreign language classes? Foreign Language Annals, 33 (2), 205-223.

Falk, J. H., \& Dierking, L. D. (2000). Learning from museums: Visitor experiences and the making of meaning. Walnut Creek, CA.: AltaMira Press.

Falk, J. H., \& Dierking, L. D. (2002). Lessons without limit: how free-choice learning is transforming education. Walnut Creek, CA: AltaMira Press.

García, C. (1991). Using authentic reading texts to discover underlying sociocultural information. Foreign Language Annals, 24 (6), 515-526. 
Handelsman, M. M., Briggs, W. L., Sullivan, N., \& Towler, A. (2005). A measure of college student course engagement. The Journal of Educational Research, 98 (3), 184-191.

Heinz, S. M. (2010). Opera in the foreign language classroom: Learning German with Mozart, Wagner, Weber, and Johann Strauss. Die Unterrichtspraxis/Teaching German, 43 (1), 49-60.

Hooper-Greenhill, E. (1992). Museums and the shaping of knowledge. London: Routledge.

Knapp, T. E. (2012). Picturing German: Teaching language and literature through visual art. Die Unterrichtspraxis/Teaching German, 45 (1), 20-27.

Köpke, W. (1999). Die Deutschen. Fort Worth, TX: Heinle.

Küpppers, Heinrich. (1906). Wenn Sie bartlos sind [Advertisement]. Simplicissimus, 10, (40), p. 477.

Kramsch, C. (2009). The multilingual subject: What foreign language learners say about their experience and why it matters. Oxford: Oxford University Press.

Kramsch, C., \& Gerhards, S. (2012). Im Gespräch: An interview with Claire Kramsch on the "multilingual subject". Die Unterrichtspraxis/Teaching German, 45 (1), 74-82.

Lixl-Purcell, A. (1991). Stimmen eines Jahrhunderts 1888-1990: Deutsche Autobiographien, Tagebücher, Bilder und Briefe. Fort Worth, TX: Heinle.

Lyster, R., \& Ballinger, S. (2011). Content-based language teaching: Convergent concerns across divergent contexts. Language Teaching Research, 15 (3), 279-288.

Met, M. (1998). Curriculum decision-making in content-based language teaching. In J. Cenoz \& F. Genesee (Eds.), Beyond bilingualism: Multilingualism and multilingual education (pp. 35-63). Clevedon, UK: Multilingual Matters.

Mihaly, D. H. (2008). The stealth approach to critical thinking in beginning Spanish classes. In A. J. Moeller, et al. (Eds.), Turning Today's Students into Tomorrow's Stars: 2008 Report of the Central States Conference on the Teaching of Foreign Languages. (pp. 37-54). Milwaukee, WI: Robert M. Terry.

MLA Ad Hoc Committee on Foreign Languages. (2007). Foreign languages and higher education: New structures for a changed world. Profession (234-245). Also available at http://www.mla.org/pdf/forlang_news_pdf.pdf.

National Standards in Foreign Language Education Project. (2006). Standards for foreign language learning in the 21st century. Lawrence, KS: Allen Press.

Pally, M. (2001). Skills development in "sustained" content-based curricula: Case studies in analytical/critical thinking and academic writing. Language and Education, 15 (4), 279-305.

Pratt, M. L., Geisler, M., Kramsch, C., McGinnis, S., Patrikis, P., Ryding, K., \& Saussy, H. (2008). Transforming college and university foreign language departments. The Modern Language Journal, 92 (2), 284-312.

Rarick, D. O. (2010). The student-centered classroom made real: Transforming student presentations in an advanced course on technical German. Die Unterrichtspraxis/Teaching German, 43 (1), 61-69.

Rice, D. (2001). Looking into seeing: What people learn in the art museum. In D. Carr, R. Eskridge, H. Jensen Leichter, D. Rice \& A. V. F. Storr (Eds.), The Museum as a place of learning (pp. 42-49). Ithaca, NY: Cornell University Press.

Rodgers, D. M. (2006). Developing content and form: Encouraging evidence from Italian content-based instruction. The Modern Language Journal, 90 (3), 373-386.

Rutherford, W. (1987). Second language grammar: Learning and teaching. London: Longman.

Scanlan, T. (1997). Another foreign language skill: Analyzing photographs. In P. R. Heusinkveld (Ed.), Pathways to culture: Readings on teaching culture in the foreign language class (pp. 351-362). Yarmouth, ME: Intercultural Press.

Schulz, R. A. (1998). Using young adult literature in content-based German instruction: Teaching the Holocaust. Die Unterrichtspraxis/Teaching German, 31 (2), 138-147.

Short, D. J. (1993). Assessing integrated language and content instruction. TESOL Quarterly, 27 (4), 627-656.

Shuh, J. H. (1999). Teaching yourself to teach with objects. In E. Hooper-Greenhill (Ed.), The Educational Role of the Museum (pp. 80-91). London and New York: Routledge.

Stoller, F. L. (2004). Content-based instruction: Perspectives on curriculum planning. Annual Review of Applied Linguistics, 24, 261-283.

Streitwieser, B., \& Lys, F. (2008). "I asked my parents why a wall was so important": Teaching about the GDR and post-reunification Germany. Die Unterrichtspraxis/Teaching German, 41 (2), 134-143.

Stroupe, R. R. (2006). Integrating critical thinking throughout ESL curricula. TESL Reporter, 39 (2), $42-61$.

Stryker, S. B., \& Leaver, B. L. (1997). Content-based instruction: Some lessons and implications. In S. B. Stryker \& B. L. Leaver (Eds.), Content-based instruction in foreign language education: Models and methods (pp. 285-319). Washington, D.C.: Georgetown University Press.

Tran, L. U. (2007). Teaching science in museums: The pedagogy and goals of museum educators. Science Education, 91 (2), 278-297.

Weitz, E. (2007). Weimar Germany: Promise and Tragedy. Princeton, NJ: Princeton University Press. 


\section{Appendix A. Essay Prompts}

Below are two examples of essay prompts. Students wrote three essays during the semester, and the prompts always included an open-ended option allowing students to explore a topic of their choice. The prompts should require that students engage reflexively and personally with the materials.

1. Schreiben Sie eine Debatte zwischen 2 Menschen über die „neue Frau“. Welche Argumente benutzen sie? (Das ist eine kreative Option-viel Spaß damit!)

2. Stellen Sie sich vor, Sie sind Deutscher oder Deutsche und Sie haben dieses Flugblatt der Weißen Rose gefunden (Januar 1943). Was würden Sie denken? Welche Fragen haben Sie? Was machen Sie damit? [Flugblatt provided together with the topic]

\section{Appendix B. Web Resources for Teaching German History}

1. LeMO, Lebendiges virtuelles Museum Online, http:/www.dhm.de/lemo/home.html. Great resource for texts, images, summaries of historical persons and events.

2. German History in Documents and Images, http://germanhistorydocs.ghi-dc.org/. Archive of primary sources: texts, maps, photographs, charts. English and German versions.

3. ZEIT für die Schule, http://blog.zeit.de/schueler/geschichte/. Good starting point for finding texts, videos and links.

4. Deutsche Geschichten, http://www.deutschegeschichten.de/indexplus.asp. Interviews with Zeitzeugen, photographs, short texts, user-friendly interface.

5. ARD Mediathek, http://www.ardmediathek.de/ard/servlet/. Search for video clips on any topic, includes great short documentary pieces.

6. Spiegel Online Video, http://www.spiegel.de/video/. Short videos dealing with current exhibitions and current events related to German history. Search in "Videosuche" box.

7. The Holocaust History Project, www.holocaust-history.org. Includes dual-language texts of primary sources, e.g.: Himmler speeches.

8. German Propaganda Archive, http://www.calvin.edu/academic/cas/gpa/. Great place to find visual sources, for example Nazi and East German posters.

9. Filmhefte, Bundeszentrale für politische Bildung, http:/www.bpb.de/shop/lernen/filmhefte/. This includes materials for teaching German films, for example Sophie Scholl: Die letzten Tage, Das Leben der Anderen.

10. Drehort Neubrandenburg, http://mmlc.northwestern.edu/neubrandenburg/, Great site from Northwestern University. Videos filmed in the former DDR in 1989 and 1999, including a Trabi lover and a third-generation farmer.

\section{Appendix C. Activity: Weimar Republic Politics}

For an activity designed to to help students better understand the diversity of political parties during the inter-war period each student received a bio of a fictional citizen and had to think about how he/she would vote in an election. In preparation, students read a text in English about Weimar political culture: Weitz's "Political Worlds" (2007, pp. 81-128). In class, I briefly introduced the political spectrum by writing the party names left to right across the board, explained the activity and then handed out the bios. Six students received printouts of authentic posters from 1920s and 30s political parties, as well as a few bullet points about each party. These six students became "party leaders" for the DNVP, DDP, DVP, Zentrum, SPD, and KPD. Students stood up and circulated around the room, trying to find a party that "their" citizen would likely vote for. The discussion afterwards focused on how the NSDAP would shift this political landscape.

Sample bios (some deliberately exaggerated, some intended to fit in multiple categories):

- Ich bin Armee-Offizier. Ich bin sehr stark nationalistisch. Ich hasse die Kommunisten. Ich bleibe dem Kaiser treu und hasse den Versailler Vertrag. Verräter!!

- Ich bin Mutter von 5 Kindern. Ich bin eine sehr katholische Frau. Die Kirche ist sehr wichtig für mich und meine Familie. Ich will, dass meine Kinder in einem katholischen Deutschland leben.

- Ich bin Arbeiter und ich will kämpfen! Ich will nicht mehr warten, ich will Aktion! Ich bin gegen den Krieg! Ich will den 8-Stunden Tag! Ich arbeite sehr viel und habe eine Familie zu Hause.

- Ich bin eine Frau und arbeite im Geschäft. Ich bin sehr froh, dass ich jetzt wählen kann. Ich will, dass Deutschland stärker wird. Wir brauchen bessere Bildung (Schulen) und eine Republik! 